\title{
Violence in South African Schools: What Is External and what is Internal to Schools?
}

\author{
Vusi Mncube \\ University of South Africa \\ Email:mncubvs@unisa.ac.za \\ Prof. Clive Harber \\ University of Birmingham and University of South Africa (Research Associate)
}

\section{Doi:10.5901/mjss.2014.v5n3p324}

\section{Abstract}

This article reports on a qualitative study that used interviews, participant observations and documents. A questionnaire was also employed. The study, which was conducted in six provinces of South Africa, explored the perceptions and experiences of school stakeholders of school violence, the nature of violence that takes place in South African schools and measures and initiatives taken by schools to promote a violence-free environment. Even though not all schools are violent, the findings suggest that violence is a serious problem in South African schools,. Some teachers are verbally, physically and psychologically violent towards learners, and frequently resort to using corporal punishment, which is illegal. The question is asked whether increased control, surveillance and punishment of learners (and staff) or better managed and organised schools is the best way to help to reduce violence. If an emphasis on the latter is to be the way forward, then this has significant implications for the recruitment, training and leadership performance of principals and for their ability to ensure more effective schools through better teacher punctuality and attendance.

\section{Introduction}

'Regrettably crime and violence in South Africa are a way of life' (Le Roux \& Mokhele, 2011:318)

'A Newcastle school principal has been suspended with immediate effect after he allegedly repeatedly punched and struck a teacher with a home-made knife in full view of teachers and pupils at the school yesterday morning...(Provincial) Spokesman Muzi Mahlambi said 'The Head of Department has just handed a letter of suspension to the principal. We cannot be urging our pupils not to carry weapons to school while teachers, especially the principal, are guilty of just that'... (the teacher said that) the principal assaulted him for his late arrival at work the previous day' (The Mercury 27/4/2012).

The above quotations from both research and media are an indication of the crisis of violence manifesting in our schools. The scourge of violence in South African schools is a cause for concern. Daily reports appear in the written and electronic media about high levels of violence, physical and sexual abuse and gang-related activities in schools. Carrying of knives, guns and other weapons is part of daily school life. Furthermore, shootings, stabbings, physical and emotional violence have taken place in both public and private schools (Akiba, LeTendre, Baker \& Goesling 2002; Zulu, Urbani \& Van der Merwe 2004:70). A report by the South African Institute of Race Relations (SAIRR) (2008) suggested that only $23 \%$ of South African pupils said they felt safe at school. In contrast, research has reported that schools in Norway, Denmark, and Sweden were the safest in the world with approximately $70 \%$ of pupils saying they felt safe at school.

'Violence' in this article is understood in the direct manner of the Gulbenkian Foundation's Commission on Children and Violence - Violence is defined as behaviour by people against people liable to cause physical or psychological harm' (1995:4). The World Health Organisation further defines violence as,

'The intentional use of physical force or power, threatened or actual, against oneself, another person, or against a group or community, that either results in or has a high likelihood or resulting in injury, death, psychological harm, maldevelopment or deprivation' (WHO, 2002:5).

Internationally, violence both affects schools and is perpetuated and perpetrated by schools (for example, Harber 2004; Pinheiro 2006; PLAN 2008; Smith \& Vaux 2003). In this article, we report on a research project on violence in schools carried out in six provinces of South Africa. This was a wide-ranging project with a number of research questions 
(Harber \& Mncube 2012). However, here we focus primarily on the types of violence the study revealed, their categorisation as 'external' or 'internal' and what the implications are for reducing violence in school. 'External' violence has an impact on the school from the surrounding society while 'internal' violence originates within the schools. We argue that such categorisations are not straightforward and are overlapping. In this article, we do not dwell on direct types of violence that primarily originate within the school such as corporal punishment and teacher verbal and sexual abuse of learners, though there is much evidence of these types of violence discussed in the sources cited above in this paragraph. Rather the focus is on forms and causes of violence that sometimes appears as purely 'external' to the school (and therefore not its fault) and the question of whether these actually have internal features as well.

\section{1 'External' and 'Internal' Violence and Schools}

There are various ways in which external violence affects schools. Violent conflict or war, for example, has an impact on education because it can potentially affect education globally. Such external conflicts have regularly directly affected the provision of schooling and in such circumstances pupils are not necessarily safe at school. This has led to a significant increase of interest in, and publications on, education during conflicts and post-conflict education (Harber 2012). Indeed, two books on education in post-conflict societies (Paulson 2011; Nicolai 2009) included chapters on South Africa, reflecting both the effects of serious levels of political violence on education during apartheid and civil violence. However, the categories of 'external' violence impacting on schools and 'internal' violence happening within schools or caused by schools are not necessarily watertight or clear cut. For example, Paulson's discussion is on the 20 year violent conflict between governments and Shining Path guerrillas in Peru (where there was also a Truth and Reconciliation Commission following the end of the fighting) which had a major impact on schools. Nevertheless, Paulson notes that Shining Path had a great deal of support membership among teachers and that,

'It helped that Shining Path indoctrination mirrored the authoritarian, didactic and unquestionable pedagogic style that had long characterised teaching and learning in Peru's state schools' (Paulson, 2011:130).

Apart from political violence and war, other forms of external violence can impact upon educational provision. For example, gang violence involving theft, drugs and weapons can extend from the surrounding community and streets into the schools where students are seen as fair game. This can take place on the way to and from school and inside school as well, especially when gang members enter school to sell drugs, steal or extort money (Le Roux \& Mokhele, 2011:318; Harber 2001). However, even this is not straightforward form of 'external' violenceas some students at the school may be in league with gang members and help and facilitate them while other students may be willing consumers of drugs. The atmosphere at the school and the sense of belonging and identity among students may be a significant factor here. An example is that of the phenomenon of school shootings that have occurred in America, such as those which took place at Columbine High in 1999. At one level, these are 'external' to the school, being caused by the problematic psychological development of the individual school members concerned and the availability of guns in American society. However, others argue that the phenomenon of rampage school shootings in American schools is not just a problem of the activities of individual pupils, - socially isolated from families, friends and communities, but essentially results from the organisational failings of schools. In each case the pupils had a troubled history, including bullying, but the schools failed to act upon their own records because information in the schools was fragmented due to the segregation of tasks and ambivalence about the key purposes of the school. As a result of this ambivalence, traditional academic concerns win out as a priority over emotional and social development. Both teachers and counsellors are not properly trained to identify and deal with personal problems and there is a dearth of resources devoted to such concerns. The pupils who eventually went on to shoot fellow pupils and teachers were not disruptive and so were not noticed,

In loosely coupled systems like schools, we argue, serious personal problems are allowed to fester because they do not impede the dominant organisational goals: order and minimum academic standards. Our study of Heath and Westside suggest that school shooters go unnoticed because many are not behaving in ways that interrupt the functioning of their schools and hence their behaviour is not interpreted as indicative of a potential for violent behaviour or of social and emotional problems' (Fox \& Harding, 2005:82).

The authors of this article also point out that at Columbine there were reports that the shooters had been viciously humiliated by their peers in the presence of their teachers, who failed to intervene on their behalf and in a number of other cases it was also reported that individual members of the school staff were aware that the shooters were being 
bullied or humiliated but did little to end the abuse. The conclusion is that these shootings did not happen by accident or on a completely random basis but were the result of interplay between the priorities of the cultural environment in which the schools operate, the organisational structure of the school and the routine cognitive practices of its staff.

There are also forms of violence which clearly have both external and internal factors. Here it is a case of where the type of violence exists or originates in the wider society but is not acted upon or is ignored by the school - violence by omission. Here we discuss three examples - racial hostility, bullying and sexual harassment. First, racial or ethnic violence, that is, hostility to the 'other' based on the colour of skin or cultural differences. There is no doubt that the wider apartheid political system and resistance to it impacted on schools in a violent way in the 1970's and 1980's. However, schools themselves have been used to overtly teach students to hate learners from another ethnic group and thus reproduce racial and ethnic tension and violence in a range of different contemporary societies (Harber, 2004). In South Africa, from 1948 to 1994, the entire education system was based on 'racial' separation and inequality with an assumed hierarchy of racial groups. Despite progress in terms of more democracy in schools since 1994, there continues to be problems of 'race' as historically defined in South Africa (Vally \& Dalamba 1999; Fataar 2007; Hunt 2007).

A second example is bullying. Bullying can take many forms - physical violence, threats, name-calling, sarcasm, spreading rumours, persistent teasing, exclusion from a group, tormenting, ridicule, humiliation and abusive comments. Bullying can be direct or indirect. Direct bullying involves physical contact or verbal abuse whereas indirect bullying involve subtle social manipulations such as gossip, spread of rumours and exclusion. A summary of research on bullying in developing countries between 2003 and 2005 (PLAN, 2008:36-41) found that between one fifth and two thirds of children reported being bullied in the previous 30 days. The same report found that the picture was similar in OECD countries. Almost a quarter of seven million students questioned in Spain and a third of those surveyed in Australia reported being bullied by classmates. The report goes on to summarise research findings from Africa, Latin America and the Caribbean and Asia, all with depressingly high levels of bullying in schools. The report points out that reducing or eliminating bullying is more difficult because many teachers (and parents) view bullying as an inevitable part school life and growing up, though this is not necessarily the case. Indeed, there is considerable evidence of the failure of schools to deal with bullying, despite being aware of its presence (Harber, 2004:3). The report by PLAN also details the consequences of bullying, loss of self-esteem, shame, anxiety, truancy, concentration problems, reactive aggression, stress and serious psychological problems and even suicide. The bullies themselves also suffer from anxiety and depression and are at a higher risk of suicide and self-harm as well as getting involved in criminal activity (PLAN, 2008:36-41).

Pupils certainly seem to be afraid of bullying. A study of fear of becoming a victim of school violence based on the percentage of pupils across 33 countries who thought another student might hurt them at least once during the previous month found that on average $25.8 \%$ thought they might do so. There was no country where almost all pupils feel safe to learn at school (Akiba, 2008). In South Africa, one study found that female learners with an intellectual disability were indeed vulnerable to sexual bullying and violence (Silanesu, 2012).

Sexual harassment is a third form of violence that is also both internal and external to schools. It is external in the sense that the type of masculine identities that lead to sexual harassment is learned by male students outside the school though family, community and the media. However, this form of violence becomes internal by omission when the school fails to deal with it. In 2008, PLAN had this to say,

'The number of children across the world subjected to sexual abuse is shocking. The World Health Organisation estimated in 2002 that 150 million girls and 73 million boys under the age of 18 had been raped or suffered other forms of sexual abuse' (2008:22).

Research for the British Department for International Development in Ghana and Botswana also found bullying, sexual harassment and aggressive behaviour by boy students against girls in schools and that such behaviour is rarely punished as teachers regard such acts as normal and a natural' part of growing up (DfID, 2005). The main cause of sexual harassment and violence in schools is that traditional gender stereotypes and unequal power relationships of the wider society are not challenged but reproduced by the school. Moreover, the authoritarian, closed nature of much of schooling meshed with patriarchal values and behaviours that provide a context in which the patterns of sexual harassment described above can happen. As the PLAN report says (2008:26),

'Girls in societies where women are accorded a lower or more passive status (and where practices such as infanticide, female genital cutting and honour killings take place) are more likely to suffer sexual violence at school'. 
The report also points out that unless teachers have been educated about gender and power issues, they are likely to model behaviour that reflects their own experiences and those of the wider community. They go on to note that a South African survey found that $47 \%$ of female teachers in a pilot project had suffered physical abuse at the hands of an intimate partner, and $25 \%$ of male teachers admitted that they had been physically abusive to an intimate partner (PLAN,2008:26).

\section{Research Methodology}

This article is based on a primarily qualitative study that also employed some quantitative research. There were a number of research objectives but one important one which is of direct relevance here was to categorise the types of violence that occur in South African schools both in terms of the nature and source of the violence.

Qualitative, semi-structured interviews with teachers, principals, members of the non-teaching staff and members of school governing bodies (SGBs) were conducted in six provinces of South Africa. Questionnaires were also administered across the six provinces in order to obtain a broader, quantitative feel for the situation across South Africa.

For the qualitative data the sample comprised the following: learners who were 14 years old had been used. Subsequently, two groups of learners were interviewed. One group consisted of learners who had been affected by violence, while the second group consisted of those learners who had perpetrated violence. A purposive sample of two teachers (the school principal and the Life Orientation teacher for Grade 9) in each school in each province was used. In addition, a purposive sample of two representatives of school governing bodies (the chair of governors and the chair of the school's discipline, safety and security committee) in each school in each province was used. Finally, a purposive sample of two members of support (general assistant and a security guard in the school) in each school in each province was used.

It is important to note that studying violence is a serious matter; therefore provision was made in the event of participants being traumatised in the process. In situations where participants were likely to be traumatised through relating traumatic experiences free psychological counselling was offered through the use of the Department of Education's district-based psychological services personnel.

Four secondary schools were selected from each of the six provinces. Criteria used for selection were based on anecdotal evidence of incidences - this evidence was garnered from media reports and conversations with 'critical friends' (e.g. teachers, principals and ward managers and school governors). The schools were chosen on the basis of their being seen as violent, as per discussion with critical friends mentioned above. Further, based on the criteria, all the schools identified were put on the short list in each province and the four most convenient schools in terms of access and proximity to the researchers were finally chosen. In total, qualitative research was done in 24 schools where interviews were conducted with the abovementioned stakeholders.

Two schools were randomly selected in each province and 100 questionnaires were self-administered in each school. Two researchers in each province self-administered a total of 200 questionnaires. In total, 1200 questionnaires were administered in all of the six provinces. The return rate of the learner questionnaire was very good. Out of 1200 questionnaires administered, 1050 were returned - a return rate of $88 \%$.

\section{Findings and Discussion}

\subsection{Types of Violence in Schools in South Africa}

While some schools said that they did not have a problem with violence, the majority of respondents did comment on incidents of violence in schools both in responses to the questionnaire and in the interviews. In relation to the questionnaires, $55 \%$ of learners responded that they had been victims of violence in schools. Of those that specified what type of violence they had experienced, 31\% said corporal punishment, 19\% bullying, 4\% sexual violence and 10\% other. There was widespread and consistent evidence of direct forms of internal violence by the schools against pupils in the form of verbal abuse and corporal punishment by teachers. However, as stated in the introduction to the article, here we are going to focus on examining and discussing some forms of violence reported in the research that are usually seen as originating externally to the school.

The key themes of externally generated themes violence impacting on the school stemming from the interviews were the role gangs, the widespread use of drugs and the carrying of weapons. However, are these solely external factors? Drugs are case in point. Drugs certainly seemed to facilitate violence in schools, but why do students take 
drugs? There are some interesting interview responses that suggest that schools are failing to provide an environment that gives students the feelings of security, confidence and sense of personal worth and well-being they need and as a result, they resort to drugs;

\begin{abstract}
It helps me to get the guts to do things that I couldn't do before. It makes me stronger and much more confident to illtreat some people and tell them that what they did to me then wasn't right (Student NWP)

Emotionally violence as I've said is when you as a person makes yourself a victim by disclosing yourself to an extent whereby you let teachers pick you and label. There shouldn't be violence because we are not being encouraged to be ourselves we turn to smoking dagga, vandalising the school in order to express ourselves. I'm not trying to shift the blame but if as I said we are encouraged to be ourselves maybe there wouldn't be such violence because everyone would be in their classes learning, but everyone is trying to avoid teacher $X$, because teacher $X$ beats the hell out of you and teacher $Y$ sees some things that displease then they make you feel small. Then you are outside, you are gambling from gambling what happens you do lose, you do lose your temper you lose everything, and you lost your money now you are trying to fight with the person who won. That's where violence starts but if you were encouraged to be yourself you wouldn't do that (Student NWP).
\end{abstract}

Also, teacher absenteeism (further discussed below) can be one of the factors in letting drug-related behaviour get out of control:

(As a result of drugs) Yes madam like if there is no teacher in the class, we kick and bang the doors and go (Student NWP).

Indeed, teacher absenteeism and lack of punctuality (of which there was considerable evidence in the research) as well as student absenteeism and lack of punctuality are factors further facilitating violence in other ways,

During the free time. Maybe there is a teachers' meeting then the fighting starts in the class (Student Focus group Gauteng).

I feel very scared when there is no teacher in class (Learner Gauteng).

When the teacher is not in the class. Some kids start fighting for the pencils or the ballpens (Student Focus group Gauteng).

I feel very scared when there is no teacher in class (Learner Mpumalanga).

.... a couple of [violence] cases [take place] in the toilets, boy's toilets...but also in the classroom...in most cases when you hear of kids fighting it's more than $90 \%$ chance that there was no teacher in that class. So it's mainly in the classroom student, KZN).

Yes, we experienced that they usually fight alone in classroom when there is no teacher ... (Teacher Limpopo)

While another Principal in Gauteng stated,

[fighting occurs] when the teacher is not present in the classroom...it does happen for the mere fact that the teacher is not there in the class, they misbehave.

Moreover, the research also found that student-to-student bullying was a key form of violence in schools but is this purely a form of externally learned behaviour? What happens, for example, when students report bullying to teachers? According to a student in Limpopo, teachers are not doing enough,

Last time when I was fighting with the other boys I was just going to the class and they said what do you want and I said I just want to talk to my friend and they slapped me and the whole class they used to beat me and I will go to the teachers and tell them that I just wanted a pen to my friend because I did not have mine and they said I was wrong to go to that class and I was not being good.

Indeed, most learners in Limpopo expressed the view that they did not raise the issue of being bullied with their teachers because they are scared and that some teachers seem to have favourites at school. A learner participant explained that,

...so when they fought I was involved and I was told I was the cause of this fight and we had to go to the disciplinary committee and no matter how hard I tried to explain I don't even know these girls whether they are cool people of the school I don't know them, [but only talk to them in class, however,] I was told that they should never see me with that girl she should go back to her cool friends I am a bad influence 
According to a student focus group in Limpopo, at times when there are fights in the school and the teachers are informed about this, they (the teachers) are not interested and do not want to get involved. Thus more learners directly or indirectly become the victims of violence in the school. According to one participant who reported being beaten by other learners at school, he was shocked by the teacher's response "They just said it's not their problem so I should go and solve it myself". "I should go and solve it myself" might easily be interpreted by the learner that he was given permission by the teacher to go and take revenge and thus do whatever it takes in the way of retaliation. Another student in Limpopo said, "I am afraid of the teachers because they won't do anything about it and if I tell them that there is someone who wants to beat me up they will ask me who is it and I will them and they will expel learner. They don't want to listen to the situation they just act on it". As a result, learners do not engage with the teachers about school activities and other relationship problems that they encounter at school. As a result, violence and bullying persists.

Moreover, there was evidence that school and local authority management did not necessarily react to issues of violence raised by learners,
Although learners are expelled they are allowed to return to school after some time which creates more problems for the victims (Learner Gauteng)
Learners are afraid to report most of the incidents for fear of victimisation (SGB member Gauteng)
Ah, mam! You just sit back with your problems. There is no use because when you tell the principal she take side on teachers (Student NWP).
In this school, I went to the principal to report what that guy did. Then the principal told me to sit down there. How does that make me feel? The person is chasing me with a knife then she tells me to sit down there, it's unfair (Student NWP). Like the principal once told us that she always take side on teachers, and she will always take side no matter what. This means the teacher is always right and then learners are always in the wrong side of everything (Student NWP).
I was too afraid to take the matter to the office because they don't take you seriously and they say ok, we are going to suspend the child for a week and you see the very child coming to school and attending the classes in the suspension (Student NWP).
Like the security here, the reason that the knives enter the school is because of low security, if they could close all the gaps and when you come in the school you are searched (Student NWP).
The poor system of registering at school in school allows trouble-some learners to drop out of school and come back when the feel like (Teacher Mpumalanga).
If reporting a teacher was not exaggerated as such as in like the learner has done something wrong, they never call these teachers to order, it's like they are saints and like these teacher think they are untouchable like they are above this law of South Africa. Teachers are busy talking about the constitution citing that the constitution says there is way of curbing violence but the teachers do not enforce it (Student NWP).

When, as found in the wider research from which this article is drawn, learners are verbally abused and physically beaten by teachers, are given the sense that they are not worried about teacher absenteeism and lateness and are ignored when they complain about being bullied and other security and safety problems in school. The resulting sense of anomie or lack of identity with the school can mean that students even collaborate with gangs and criminals outside the school, raising further issues of what is an external and what an internal cause of violence is. Here are some of the responses:

The thing is even if the school's security was tight, we make holes in the school, we cut the wires out the fences down so that those guys may come in (Student NWP).

No security in this school, like some other guys bring their friends from their areas and come to rob the children in the school (Student NWP).

The converse of this is the following examples of responses in relation to the importance of good school management, an ordered environment and teacher professionalism,

[violence] does not impact negatively upon the running of this school because of the way of life of this particular institution in terms of discipline, in terms of good work ethics, in terms of ethos, in terms of vision. So when [students] come in to these premises it changes all together. We ensure that they are at school on time...and we ensure that by the time they go out of the premises at any given time they are not the same as they were in the morning (Principal $K Z N)$.

... when they [students] come in to these premises [they] change all together. We ensure that they are at school on time, we ensure that they get their homework, we ensure that they are in class and we ensure that by the time they go out of the premises at any given time they are not the same as they were in the morning (Principal KZN). 
Teachers go to their classes and our head master is doing his job properly and the deputy so most of the time during school hours our learners are in class unless those who are moving around maybe going somewhere maybe if you have sent them somewhere to go and fetch something for you but all in all they stay in class and teachers go classes (Teacher NWP).

\section{Conclusion}

Perhaps the most disturbing part of the overall research project selectively reported on here was the evidence of direct forms of violence that originated within the school itself. It was clear that a proportion of teachers are verbally, physically and psychologically violent towards learners, including using corporal punishment which is illegal. Such direct forms of violent behaviour by teachers demonstrate a serious problem of lack of professionalism, compounded by evidence in this report of teacher behaviour which also indirectly contributes to violence - teacher absenteeism and lateness.

However, the main purpose of this article has been to examine how clear cut distinctions are between violence in schools that has its origins externally and those that originate internally. Some types of violence affecting schools, for example Gangsterism, clearly originate outside the school as do the use of illegal drugs which facilitates violence. Some forms of violent behaviour such as bullying and male student sexual harassment of female students may well be learnt in families and communities beyond the school. However, we would argue that this is not to say that there is nothing that schools can do about such external violence or, as we have seen, that such violence is completely external anyway.

First, a well organised, inclusive and well-run school can do much to reduce the incidents and impact of external violence because learners and teachers are part of an community with a sense of purpose - there is something which people feel they belong to and which is worth protecting. Such a well organised school may well have a safety and security committee which makes sure that there are proper fences, locks and etcetera but its main strength is that loyalty and commitment to the school will reduce internal collaboration with potentially violent external individuals and groups. As opposed to a dysfunctional or laissez-faire school, such external threats will be more readily noticed and acted upon in a cohesive way.

Second, as this study shows, some 'external' threats are also partly internal. Some student respondents report that the failure of the school to recognise them as individuals or to provide self-esteem promotes their use of drugs. More obviously, schools are failing to deal with cases of bullying or sexual harassment even when they are reported to teachers. This is a case of violence by omission where schools knows there is a problem of violence, which the evidence in this study clearly suggests they do, but do little or nothing to try to prevent it. Paradoxically, however, this is also good news because if a considerable share of violence affecting schools actually originates within schools themselves then they can actually do something about it. Schools are not necessarily helpless victims of a wider violent society.

\section{References}

Akiba, M. 2008 'Predictors of Student Fear of School Violence: A Comparative Study of Eighth Graders in 3 Countries', School Effectiveness and School Improvement 19,1 pp51-72.

Akiba, M. LeTendre, G. K., Baker, D.P. \& Goesling, B. 2002 'Student victimisation: National and School System Effects on School Violence in 37 Nations', American Educational Research Journal Vol. 39(4) 829-853.

Fataar A 2007. 'Educational renovation in a South African township on the move: a social-spatial analysis', International Journal of Educational Development, 27,6pp 599-612.

Fox, C. \& Harding, D. 2005. 'School Shootings As Organisational Deviance', Sociology of Education 78, pp 69-97.

Gulbenkian Foundation (1995) Children and Violence, London: CalousteGulbenkian Foundation.

Harber,C. 2012 'Education In and After Violent Conflict: Stability and the Status Quo or Transformation and Peace?', Review Essay, International Journal of Educational Development pp. 213-216.

Harber, C. 2004 Schooling As Violence: How Schools Harm Pupils and Societies London: RoutledgeFalmer.

Harber, C. 2001. State of Transition: Post-Apartheid Educational Reform in South Africa (Oxford: Symposium Books)

Mncube, V.S \& Harber CR 2012. The Dynamics of Violence in Schools in South Africa: A Report on a Research Study UNISA: Pretoria. Hunt, F. 2007. Schooling Citizens: a study of policy in practice in South Africa, Unpublished Doctoral Thesis, University of Sussex.

Id21 2005. ' Making the difference: how schools influence gender identity' Research Highlight 25/1/2005.

Le Roux, C.S. \& Mokhele P. R 2011. 'The persistence of violence in South Africa's schools: In search of solutions', Africa Education Review 8 (2) pp. 318-335.

Nicolai,S. (Ed.) 2009 Opportunities for Change; Education Innovation and Reform After Conflict Paris:IIEP and UNESCO.

Paulson, J. (Ed.) 2011. Education and Reconciliation: Exploring Conflict and Post-Conflict Situations () London: Continuum

Pinheiro, P. 2006. World Report on Violence Against Children. Geneva: United Nations.

PLAN (2008) The Global Campaign To End Violence in Schools. Woking: PLAN. 
Silanesu, A. 2012 in press. 'School-based sexual violence amongst learners with intellectual disability in South Africa: contributory factors', International Journal of Disability, Development and Education - forthcoming.

Smith, A. \& Vaux, T. 2003 Education, Conflict and International Development. London:DfID.

South African Institute of Race Relations, 2008. South African schools most dangerous in the world Accessed on 01/03/2010,from http://www.saiir.org.za/press.

Vally, S. \& Dalamba, Y. 1999. Racism, Racial Integration and Desegregation in South African Public Secondary Schools. Johannesburg: South African Human Rights Commission.

WHO (World Health Organisation) 2002World Report on Violence and Health Geneva :WHO.

Zulu, B.M., Urrbani, G. \& Van der Merwe, A. 2004. 'Violence as an impediment to a culture of teaching and learning in some South African schools', South African Journal of Education 24(2) 170-175. 